\title{
Važniji štetnici šipka na području Hercegovine
}

\section{Sažetak}

Šipak (Punica granatum) se u Hercegovini uzgaja na površini od 54,41 ha. U okviru 58 intenzivnih nasada šipka evidentirano je 43.248 stabala ove voćne vrste. Podizanjem intenzivnih nasada u uzgoju šipka pojavili su se brojni štetnici koji ugrožavaju proizvodnju i izazivaju ekonomski značajne štete. Značajniji štetnici u nasadima šipka na području Hercegovine su: Myzus persicae, Siphoninus phillyrea, Ceratitis capitata i Zeuzera pyrina. U radu će biti prikazane biološke i ekološke karakteristike štetnika te mogućnosti zaštite šipka.

Ključne riječi: Intenzivni nasadi šipka, štetnici, ekonomski značajne štete

\section{Uvod}

Šipak je voćna kultura koja se se u Hercegovini najviše uzgaja na području Mostara, Ljubuškog, Stoca i Čapljine. Prema inventarizaciji šipka u Hercegovini koju je proveo Federalni agromediteranski zavod Mostar u razdoblju 2011./2012. godina evidentirano je 58 vlasnika intenzivnih nasada šipka. Najveći broj nasada nalazi se na području općine Mostar (23 nasada ili $39,66 \%$ ), općine Ljubuški (14 nasada ili 24,14 \%), općine Stolac (10 nasada ili 17,24 \%), općine Čapljina (9 nasada ili 15,52 \%) dok je po jedan nasad evidentiran na području općine Neum $(1,72 \%)$ i Grude (1,72 \%). Ukupna površina pod nasadima šipka iznosi 54,41 ha u kojima se uzgaja 43.248 stabala šipka, s gustoćom sklopa 4x3 m (kod 44,83 \% nasada). Sortiment je različit, ali prevladavaju sorte koje se tradicionalno uzgajaju u Hercegovini: Barski slatki - 15.365 stabala (38,18 \%), Glavaš - 12.822 stabala (31,86 \%), Konjski zub - 3.526 stabala (8,76 \%), Hercegovački sladun - 2.672 stabala (6,64 \%) i brojni drugi. Zbog velike ekonomske isplativosti koja se ogleda u prodaji soka od divljeg šipka ne začuđuje evidentiranih 4.315 stabala divljeg šipka (10,72 \%) koji se uzgajaju u sklopu intenzivnih nasada. Gotovo svi nasadi imaju osigurano navodnjavanje $(93,10 \%)$, uglavnom kroz instaliran sustav kap po kap. Što se tiče plasmana proizvoda uočeno je kako 85,48 \% proizvođača na tržište plasira svježe plodove dok sok od šipka proizvodi 12,90 \% proizvođača, a samo 1,62 \% i druge proizvode tj. prerađevine od šipka. Premda dio proizvođača sadni materijal proizvodi u vlastitoj režiji, razmnožavanjem zrelim i zelenim reznicama veliki dio njih sadnice nabavlja u registriranim rasadnicama i maloprodajnim objektima koji oni opskrbljuju. Tako je u pet registriranih rasadnika voćnih sadnica u 2009. godini proizvedeno 45.810 kontejniranih sadnica šipka, 2010. godine 48.500 komada, 2011. godine 80.550 komada i 2012. godine 78.015 sadnica (Federalni agromediteranski zavod Mostar, 2012).

Tijekom obilaska intenzivnih nasada šipka na području Hercegovine zapaženo je kako vlasnici nasada i rasadničari imaju poteškoća s pojavom zelene breskvine uši i jasenovog štitastog moljca, a vlasnici nasada na određenim lokalitetima i s mediteranskom voćnom muhom te granotočom. Na pojedinim mikrolokalitetima kao štetnici stabala šipka pojavljuju se skakavci i puževi s kućicom koji ne izazivaju značajnije štete. Još jedan štetnik vezan je za plodove šipka, a to je uholaža koja ne čini izravne štete već stvara nelagodu krajnjim korisnicima plodova 
šipka skrivajući se na vrhu ploda u vijencu od preostalih čašičnih listića koje onečišćuje svojim izmetom.

\section{Značajniji štetnici šipka}

Zelena breskvina lisna uš (Myzus persicae Sulz.) je izrazito polifagna vrsta koja napada veliki broj poljoprivrednih kultura. Najveće štete čini na breskvama i nektarinama zbog čega je i dobila ime. Dok je duhan bio dominantna kultura u Hercegovini uš je činila velike štete i u rasadu i na otvorenom polju, utječući čak i na promjenu kemijskog sastava jer je dovodila do smanjanja glukoze kao vrijedne komponente duhana. Danas se pak redovito pojavljuje u nasadima šipka gdje u godinama pogodnim za njen razvoj izaziva velike štete. Prenosi veliki broj perzistentnih i neperzistentnih virusa.

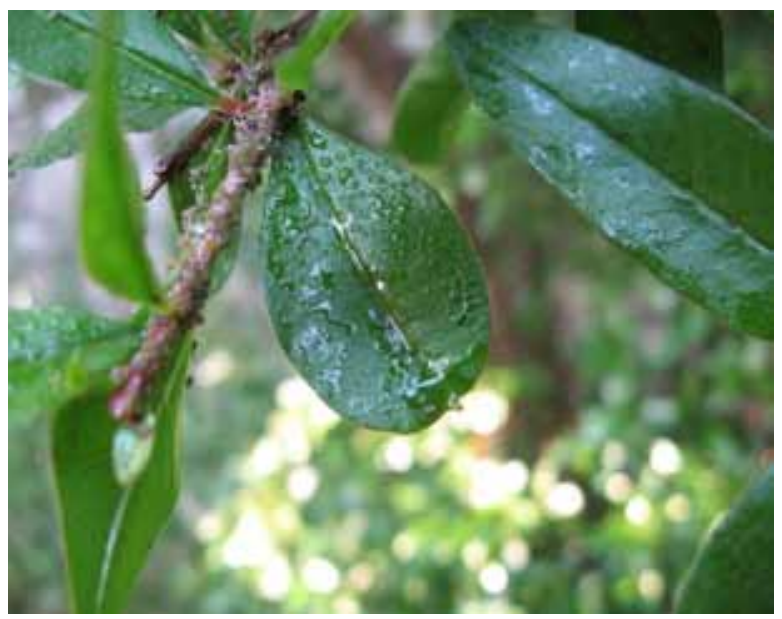

Slika/Figure 1. Kapljice medne rose na listovima šipka Izvor/Source: Autori

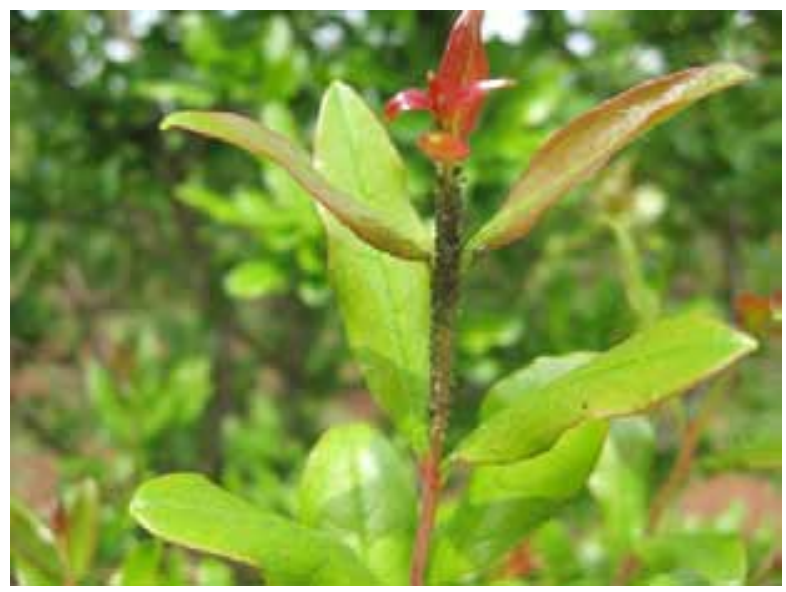

Slika/Figure 2. Lisne uši na izboju šipka Izvor/Source: Autori 


\section{Opis štetnika i životni ciklus}

Odrasle krilate jedinke su žutozelene do maslinastozelene boje, s tipičnom pjegom na zatku. Tijelo im je dugo 1,4 do 2,1 mm, izduženo-ovalnog oblika s glavom i prsištem crne boje te relativno dugim, tankim cjevčicama na zatku (sifoni) koje su priljubljene uz tijelo. Imaju dva para dugih, prozirnih krila sa slabo razvijenom nervaturom. Beskrilne forme imaju svijetlozelenu ili žućkastu boju i veličinu 1,7-2,0 mm. Jaja su 0,6 mm duga i 0,3 mm široka, ovalnog oblika i sjajno crne boje. Uš prezimi kao zimsko jaje na kori grana breskve koja joj je zimski domaćin (može prezimiti i na drugim Prunus vrstama). U zaštićenim prostorima prezimi kao odrasla ženka, a posljednjih godina u južnim predjelima Hercegovine i na otvorenom pa uš razvija veći broj generacija nego što je to uobičajeno jer se stalno partenogenetski razmnaža. Eklozija ličinki fundatriksa u Hercegovini počinje tijekom veljače, a njen tijek ovisi o klimatskim parametrima, prvenstveno temperaturi. Kod ove polivoltne vrste prve apterne kolonije stvaraju se na breskvi na kojoj se razvije nekoliko generacija. Broj generacija ovisi o vladajućim klimatskim parametrima i pri srednjoj dnevnoj temperaturi od 20 stupnjeva ${ }^{\circ} \mathrm{C}$ razvoj jedne generacije traje 10-12 dana. Na breskvi se uši zavlače u nabubrele cvjetne pupove gdje usnim ustrojem koji je podešen za bodenje i sisanje sišu njihove sokove. Posebno je štetno što uš bode plodnicu cvijeta i siše sokove. U dugoj dekadi travnja i početkom svibnja javlja se prva krilata generacija koja se seli na sekundarne domaćine. Prije selidbe na ljetne domaćine kao što je šipak zelena uš čini velike štete na stablima bresaka. Broj krilatih jedinki se povećava iz generacije u generaciju tako da cjelokupna populacija nestaje s bresaka koncem lipnja. Tijekom srpnja prevladavaju krilate forme uši koje se dalje raseljavaju i to je razdoblje kada dolazi do intenzivnog širenja virusa. Zbog velikih vrućina i fiziološkog stanja uzgajanih biljaka tijekom kolovoza na ljetnim domaćinima brojnost ušiju se smanjuje da bi se koncem rujna seksupare ženke vratile na primarnog domaćina tj. breskve. One daju generaciju beskrilnih ženki koje nakon kopuliranja s krilatim mužjacima koji na breskvu dolijeću s ljetnih domaćina, odlažu zimska jaja. Pošto posljednjih godina u Hercegovini tijekom listopada i studenog prevladava toplo vrijeme ovipozicija tj. polaganje jaja na breskvama se se odvija potpuno nesmetano pa je i ukupan broj položenih jaja puno veći u odnosu na godine kada se u ovom razdoblju pojavljuju niske temperature. Ocjena intenziteta napada zelene breskvine uši upravo se vrši tijekom zime na osnovu broja odloženih jaja te u svibnju na osnovu formiranih kolonija i broja napadnutih izboja po stablu.

\section{Štete na šipku}

Zelena breskvina uš može prouzročiti velike štete u nasadima šipka. Kao posljedica njene ishrane na biljnim organima pojavljuju se različiti simptomi. Karakteristični simptomi javljaju se na listovima gdje se obično nalazi najveći broj jedinki lisnih ušiju. Kao posljedica sisanja biljnih sokova listovi se deformiraju, kovrčaju, a kod jačeg napada dolazi i do njihovog sušenja. Osim toga, uši luče mednu rosu na kojoj se razvijaju gljive čađavice zbog čega se umanjuje asimilacijska površina te se ometaju procesi fotosinteze, skraćuje se vegetacija i cijela biljka ima slabiji rast i razvoj (Vego i sur., 2009). Mednom rosom hrane se mravi te je njihova prisutnost na biljci prvi i najočitiji znak prisutnosti lisnih ušiju. Pored listova zelena breskvina uš na šipku napada izboje, cvjetove i plodove. U ekstremnim slučajevima velike kolonije ušiju na plodovima šipka dovode do njihove kloroze i slabije obojanosti. Stabla šipka obilnije gnojena organskim i dušičnim gnojivima, a koja imaju osigurano navodnjavanje formiraju bujnija stabla i izboje podložnija su napadu ove lisne uši. Uš preferira mlađe zelene dijelove biljaka pa naseljava i oštećuje razgranate vrhove izboja koji su obrasli listovima premda je kod jačeg napada nalazimo u čitavoj krošnji. Zelena breskvina uš je jedna od najaktivnijih vektora virusa jer je izraziti polifag koji oštećuje veliki broj biljnih vrsta. 


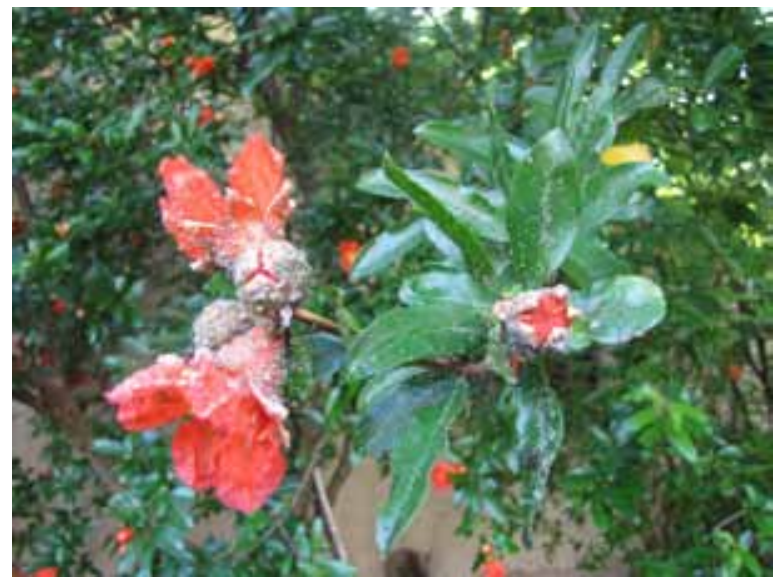

Slika/Figure 3. Jak napad lisnih uši na šipku Izvor/Source: Autori

\section{Suzbijanje}

Praćenje pojave i leta zelene breskvine lisne uši vrši se postavljanjem žutih ljepljivih ploča u krošnje stabala šipka. Suzbijanje se provodi kada se na naličju mladog lišća počnu uočavati kolonije lisnih ušiju. Danas na tržištu postoje brojni pripravci koji djeluju na ovu lisnu uš premda svi nemaju dozvolu za korištenje na šipku. Stoga kod izbora pripravaka prednost treba dati selektivnim i ekološki prihvatljivijim insekticidima. Naime, u nasadima šipka nalaze se brojne korisne vrste od kojih su mnoge prirodne neprijatelji ove lisne uši. Najvažniji predatori su božje ovčice, ličinke zlatooka, osolike muhe, bogomoljke te brojne vrste grabežljivih stjenica. Nadalje, medna rosa koju obilno luče lisne uši privlači pčele o čemu također treba povesti računa kod izbora pripravaka. Za suzbijanje zelene breskvine lisne uši u praksi se najčešće koriste insekticidi iz skupine neonikotinoida (imidakloprid, tiametoksam, tiakloprid i acetamiprid). $U$ zadnje vrijeme za suzbijanje lisnih uši koriste se pripravci na osnovi flonikamida.

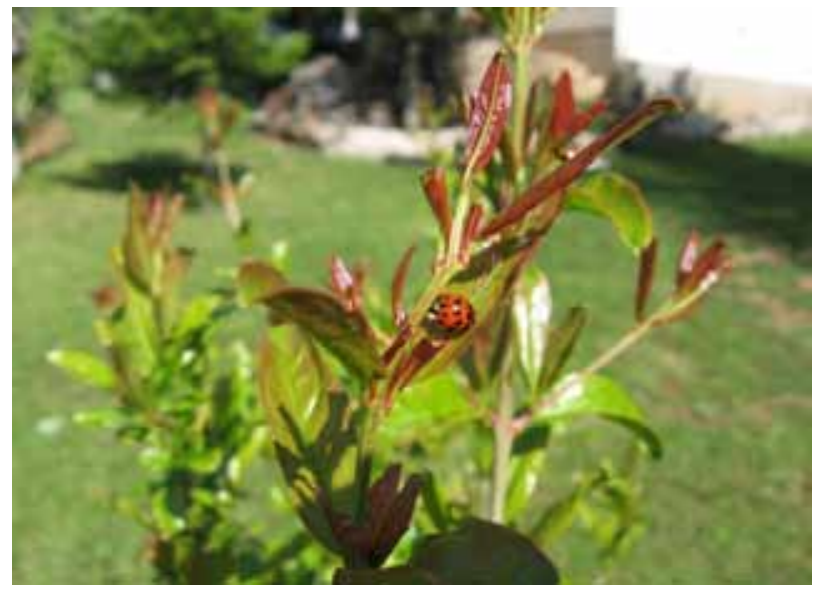

Slika/Figure 4. Božja ovčica važan predator lisnih ušiju Izvor/Source: Autori 


\section{Jasenov štitasti moljac (Siphoninus phillyrea Hal.)}

Ova vrsta je izvorna u regiji Mediterana (Martin i sur., 2000). U Egiptu predstavlja najvažnijeg štetnika šipka (Malumphy, 2010). Tijekom proljeća 2008. godine u okolici Mostara, Ljubuškog i Čitluka prvi put zabilježena je jača zaraza šipka jasenovim štitastim moljcem, a što se na istim lokalitetima ponovilo 2010., 2014., 2016. i 2017. godine. Najveća brojnost ovog štetnika uočena je na sortama Glavaš i Konjski zub (Rotim i Ostojić, 2014). Što je, osim intenziviranja uzgoja šipka, pridonijelo povećanoj brojnosti jasenovog štitastog moljca u Hercegovini (ali i regiji) nije poznato. Postoje samo pretpostavke. Tomu je svakako pridonijela i činjenica kako je proučavanje jasenovog štitastog moljca na našem podneblju godinama bilo zanemarivano. Jedna od pretpostavki koja je donekle potkrijepljena činjenicama jest kako štetnik ima veće šanse za održavanje u novim, intenzivnim nasadima šipka koji se redovito navodnjavaju. Ukoliko je poznato da od ukupno 58 proizvođača šipka u Hercegovini njih $93 \%$ ima osiguran sustav navodnjavanja jasno je da to može biti jedan od razloga povećane brojnosti ovog, ali i drugih štetnika. Redovita opskrba vodom i postojanje sustava za navodnjavanje preduvjet su češće primjene gnojiva što uz gusti sklop sadnica također utječe na stvaranje povoljnijih mikroklimatskih uvjeta za razvoj štetnika. Širenju jasenovog štitastog moljca svakako je pridonijela učestala primjena insekticida širokog spektra djelovanja čime su se u velikoj mjeri uništili njegovi prirodni neprijatelji. Zaraze većeg intenziteta dovode do otpadanja listova, rane defolijacije i formiranja plodova manje veličine (Bellowes i sur., 1990).

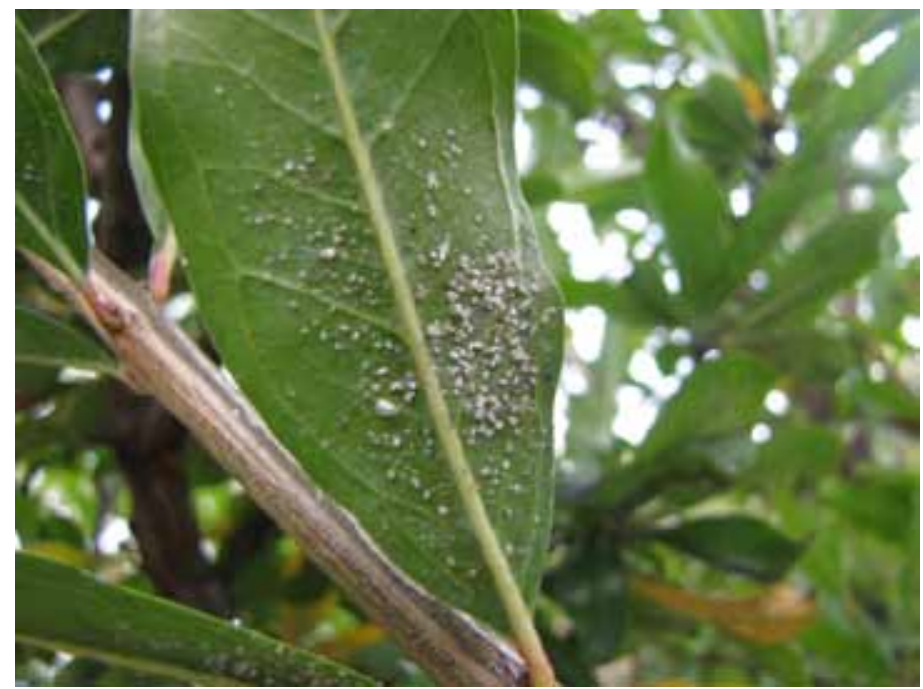

Slika/Figure 5. Ličinke i odrasli oblik jasenovog štitastog moljca na naličju lišća Izvor/Source: Autori

\section{Morfološke značajke vrste}

Jasenov štitasti moljac, kao i druge vrste štitastih moljaca, prolazi tri razvojna stadija: odrasli oblik, jaje i nimfa-ličinka (četiri stadija od kojih se posljednji, četvrti prestaje hraniti i formira puparium-„,kukuljicu“).

Odrasli oblici jasenovog štitastog moljca se teško razlikuju od ostalih vrsta štitastih moljaca. Krila su im prekrivena bijelim voštanim prahom, glava i tijelo su žute boje dok su oči crvene. Duljina tijela iznosi oko 1,7 mm. Mogu se naći na naličju listova biljaka domaćina, gdje odlažu jaja ili među kolonijama pupariuma iz kojih su netom izišli. Ukoliko se zanjišu grane jako zara- 
ženih biljaka, izlijeću oblaci "bijelih mušica". Jaja su žuto-bijele boje, izduženo eliptičnog oblika i prekrivena su vrlo tankim slojem bijelog voštanog praha. Naime, nakon ovipozicije ženka prekriva jaja voštanim prahom kako bi ih zaštitila od isušivanja i ostalih nepovoljnih vanjskih utjecaja. Starenjem i razvojem jaja ubrzo posmeđe. Ženka odlaže jaja na naličju listova u skupinama u obliku kružnice. Na bazalnom dijelu jaja su kratkom stapkom čvrsto pričvršćena za list.

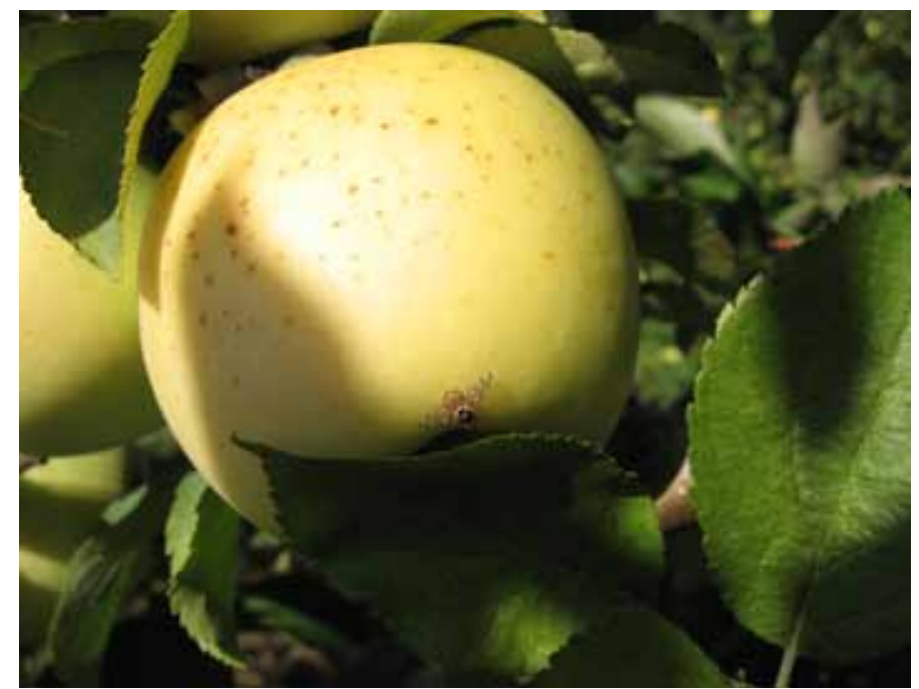

Slika/Figure 6. Mediteranska voćna muha odlaže jaja na plod zlatnog delišesa Izvor/Source: Autori

Nimfa (ličinka) prvog razvojnog stadija je dugačka oko 0,3 mm, produljena oblika, plosnata i gotovo prozirna te jedina, od nimfalnih stadija, gibljiva premda rijetko prevali udaljenost veću od $10 \mathrm{~mm}$. Tijekom razvoja, nimfe proizvode 40 - 50 staklastih cjevastih bodlji raspoređenih po leđnoj strani tijela boje meda. Ove strukture, teško vidljive okom, izlučuju kapljice staklastog voska što doprinosi posebnosti izgleda nimfe i pupariuma - odlika vrste. Nimfu četvrtog stadija karakteriziraju dva uzdužna niza bijelih voštanih nakupina na hrbatu ispod kojih se nazire smeđe označen središnji dio tijela. Pojas oko ekskrecijskog otvora je također smeđe boje. Posljednji nepokretni stadij se naziva puparium. Izgledom je vrlo sličan nimfi četvrtog stadija. Duljina tijela pupariuma iznosi 0,8 - 1,0 $\mathrm{mm}$ a širina 0,55-0,7 $\mathrm{mm}$.

Mogućnosti suzbijanja

Jasenov štitasti moljac je štetnik manjeg značaja u onim predjelima gdje su sačuvani njegovi prirodni neprijatelji. Brojni su parazitoidi, predatori i entomopatogene gljivice važni za smanjenje brojnosti ovog štetnika u poljoprivrednim ekosustavima. Među njima je najučinkovitija parazitska osica Encarsia inaron (Abd-Rabou,1998). Istraživanjem u voćnjacima kruške na Siciliji je dokazano kako od ukupne parazitacije, 80 \% pripada upravo ovoj vrsti. Osica se komercijalno uzgaja u Izraelu i Italiji te ispušta primjerice u Kaliforniji (Pickett i sur., 1996) i Novom Zelandu gdje se postiže visoka parazitacija štetnika.

Praćenje pojave i leta jasenova štitastog moljca vrši se postavljanjem žutih ljepljivih ploča u krošnje stabala šipka (Ostojić $i$ sur.,2014). U predjelima gdje su prirodni neprijatelji uništeni učestalim primjenama insekticida širokog spektra, jasenov štitasti moljac može postati važan štetnik. Premda su brojni insekticidi registrirani za suzbijanje štitastih moljaca, njihovom pri- 
mjenom se ne postiže trajnija redukcija ovog štetnika. Kemijska sredstva, neonikotinoidi primjerice, osiguravaju dobru početnu učinkovitost u suzbijanju štetnika ali dolazi do ponovne zaraze s okolne vegetacije. Dobri rezultati postižu se primjenom flonikamida.

Ukoliko se odlučimo za primjenu kemijskih insekticida, važno je postići pokrivanje naličja listova, a potrebu ponavljanja mjere utvrditi temeljem vizualnog pregleda. Radi smanjivanja površinske napetosti i boljeg prianjanja apliciranih pripravaka poželjno je koristiti okvašivače. Na okućnicama gdje se uzgajaju pojedinačna stabla korisna mjera jest sapiranje štetnika sa biljke mehaničkim putem odnosno jačim mlazom vode.

Uništavanjem biljnog materijala koji je zaražen ovim štetnikom, te različitih biljaka domaćina oko voćnjaka ili rasadnika, smanjuje se reprodukcijski potencijal štetnika.

\section{Mediteranska voćna muha (Ceratitis capitata Wied.)}

Mediteranska voćna muha je izrazito polifagna vrsta koja napada i oštećuje preko 200 biljnih vrsta. Najveće štete nanosi voćnim vrstama čiji su plodovi mekane konzistencije. U Hercegovini ekonomski značajna oštećenja nanosi u nasadima bresaka i nektarina, ali i na plodovima agruma, smokava, kakija, marelica i jabuka (Bulić i sur., 2012). Posebno su ugroženi mješoviti nasadi jer kada se završi berba bresaka i drugih ranijih voćnih kultura muha prelazi na nedozrele ili poluzrele plodove jabuka kao što je to evidentirano u Popovu polju (općina Ravno) 2010. godine (Bulić i sur., 2010). Sve sorte jabuka nisu podložne napadu ovog štetnika, ali je posebno osjetljiv Zlatni delišes. Mediteranska voćna muha napada i intenzivne nasade šipaka u unutrašnjosti Hercegovine premda nisu pošteđena ni pojedinačna stabla na hercegovačkom primorju. Naime, u općini Neum gdje se u sklopu okućnica i vikend naselja u konsocijaciji uzgajaju pojedinačna stabla mandarina, naranača i šipaka zamijetno je kako muha nakon berbe citrusa, u nedostatku poželjnijeg domaćina, prelazi na plodove šipka. Tijekom petogodišnjih istraživanja, provedenih na području Hercegovine, pronađeno je 9 biljaka domaćina mediteranske voćne muhe svrstanih u 5 porodica (Ostojić $i$ sur.,2014).

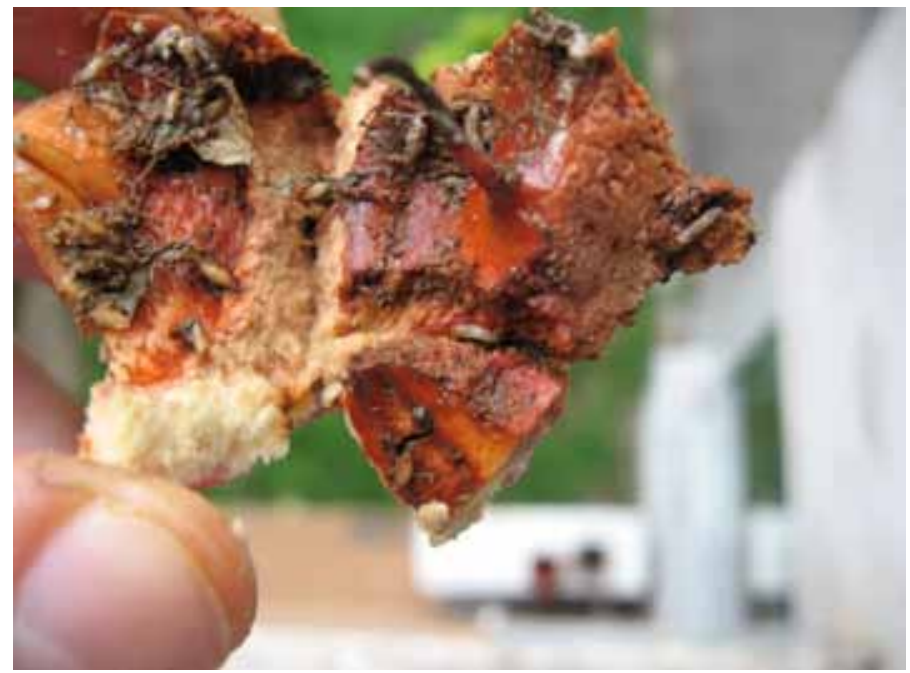

Slika/Figure 7. Ličinke mediteranske voćne muhe u plodu šipka Izvor/Source: Autori 


\section{Opis štetnika i životni ciklus}

Odrasla muha je žutosmeđe boje sa žutim poprečnim prugama na prozirnim krilima čiji je raspon 8-11 mm. U mirovanju muha drži krila razmaknuta. Dužina tijela iznosi 3,5-5 mm. Glava je velika, blijedožute boje dok je toraks kremastosive boje s karakterističnim crnim zonama. Zadak je žute boje s dvije poprečne sive pruge i kod ženke završava oštrom legalicom dugom 1,2 mm. Jaja su vretenastog oblika i bijele boje. Apodna ličinka je blijedožute boje, valjkastog oblika i u predjelu glave sužena (zašiljen oblik), duljine do $7 \mathrm{~mm}$. Kukuljica je cilindričnog oblika, crvenosmeđe boje i dužine 4-4,3 mm. Broj generacija koje razvije ovaj štetnik prvenstveno ovisi od klimatskih uvjeta podneblja. Na području Hercegovine mediteranska voćna muha razvije 4-5 generacija (Peljto $i$ sur., 2007). Prezimi kao kukuljica u tlu na dubini od 3-5 cm ili kao imago u različitim skrovištima na zaklonjenim mjestima unutar voćnjaka. Tijekom svibnja pojavljuju se prve muhe koje nakon kopulacije odlažu nekoliko stotina jaja u poluzrele ili zrele plodove. Najveći broj jaja voćna muha odlaže u raspukle plodove šipka premda svojom oštrom legalicom jaja može odložiti i u njegove neoštećene plodove. Ženke žive 20-30 dana i jaja odlažu u površinski dio zdravog ploda u skupinama od 10-20 jaja. U isti plod jaja mogu odložiti i druge ženke pa se u jednom plodu može nalaziti veći broj ličinki. Embrionalni razvoj u tijeku leta traje 2-3 dana nakon čega izlaze ličinke koje se ubušuju u unutrašnjost ploda. Svoj razvoj ličinka završava za 7-18 dana, ovisno od toga u plodu koje voćne vrste se razvija. Uslijed ishrane ličinki plodovi gube na svježini i izgledu te prijevremeno padaju na tlo ispod stabla voćke. Ličinke napuštaju unutrašnjost otpalog ploda kroz otvor koji sami načine i kukulje se u tlu. Ukoliko plodovi ostanu visjeti na krošnji stabla ličinke na rubu izlaznog otvora savijaju tijelo u luk te se naglim ispružanjem odbacuju iz ploda i padaju na tlo. Stadij kukuljice traje 10-20 dana nakon čega se pojavljuje nova generacija muha čime se životni ciklus ponavlja. Ličinke zadnje generacije koje plodove napuste koncem rujna odnosno početkom listopada ostaju u tlu u formi kukuljice do narednog proljeća.

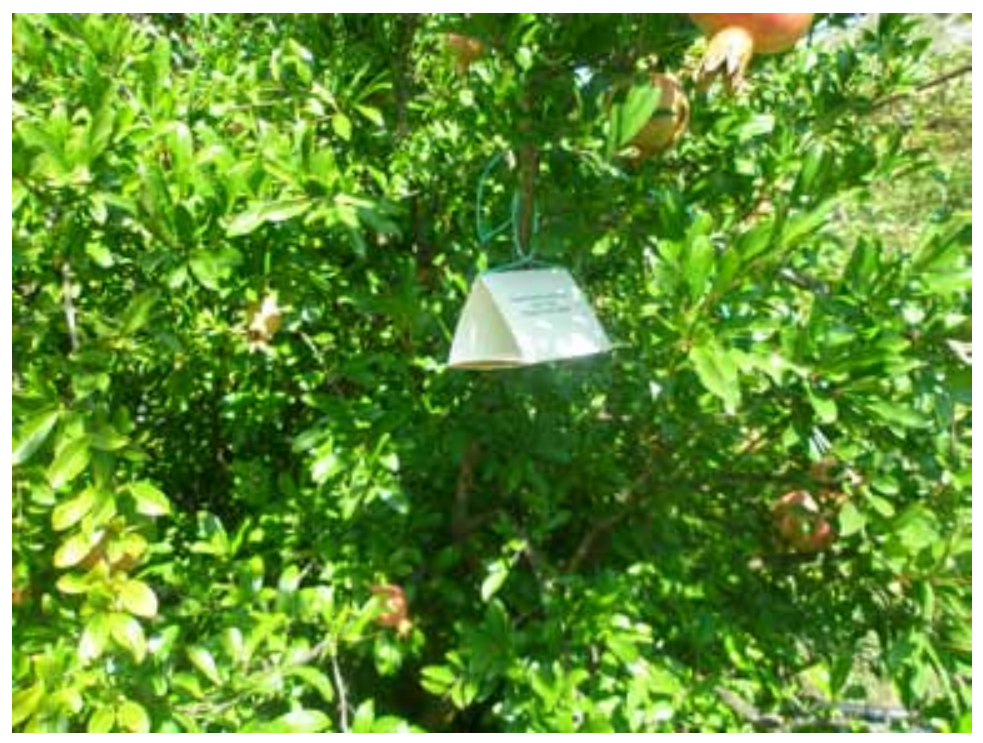

Slika/Figure 8. Lovka za mediteransku voćnu muhu Izvor/Source: Autori 


\section{Suzbijanje}

Suzbijanje mediteranske voćne muhe predstavlja kompleksan problem. Niske temperature tijekom zime mogu da prouzroče visok mortalitet kukuljica i time znatno smanje brojnost muha u proljeće. Pojava i let muha prati se putem postavljenih žutih ljepljivih ploča i lovnih posuda s različitim mamcima (ulje od angelike, sintetski atraktanti). Često se u jednom voćnjaku koriste vizualni i olfaktorni mamci čime se utvrđuje prisutnost i intezitet pojave muhe, što je preduvjet za utvrđivanje optimalnog roka suzbijanja. U Hercegovini su se praktičnim pokazali mamci s atraktantom trimedlure postavljeni u nasadima mediteranskog voća (Ortiješ kod Mostara) putem kojih se za samo tjedan dana hvatalo preko 150 odraslih muha, a na području Popova polja (općina Ravno) i Blagaja (općina Mostar) i nekoliko stotina muha kroz razdoblje od 20-25 dana.

$\mathrm{U}$ istraživanjima brojnosti mediteranske voćne muhe, na području Hercegovine, u periodu 2009-2013. godina, utvrđene je najveća brojnost ovog štetnika na području Popova polja (općina Ravno) u 2012. godini, kada je početkom listopada,u jednom danu, ulov u lovci iznosio preko 120 jedinki (Ostojić i sur.,2014).

Jedna od najčešćih mjera suzbijanja jest primjena kemijskih pripravaka. Danas se na tržištu mogu nabaviti različiti pripravci za suzbijanje mediteranske voćne muhe, ali pošto nemaju dozvolu za primjenu na šipku potreban je oprez kako ne bi došlo do pojave fitotoksičnosti. U zadnje vrijeme se koristi metoda lokaliziranog tretiranja tj. tretiranja dijelova nasada insekticidima duljeg rezidualnog djelovanja uz dodatak atraktanta (Buminal). Korisna mjera jest sakupljanje otpalih plodova u kojima se nalaze ličinke i njihovo uništavanje. Otpale plodove nije poželjno ukopavati u tlo pošto muha može izaći iz dubljih slojeva tla i time nastaviti svoj razvoj već ih je potrebno zapaliti ili pakirati u plastične vreće u kojima se drže na suncu 10-tak dana. Korisna mjera provodiva na pojedinačnim stablima u sklopu okućnica jest omatanje plodova papirnim vrećicama čime se onemogućuje odlaganje jaja. Godine 2011. godine na području Popova polja prakticirana je autocidna metoda suzbijanja mediteranske voćne muhe ispuštanjem sterilnih mužjaka što uz druge mjere zaštite može polučiti zadovoljavajuće rezultate $u$ cilju smanjenja populacije i brojnosti ovog štetnika (Bulić $i$ sur., 2012).

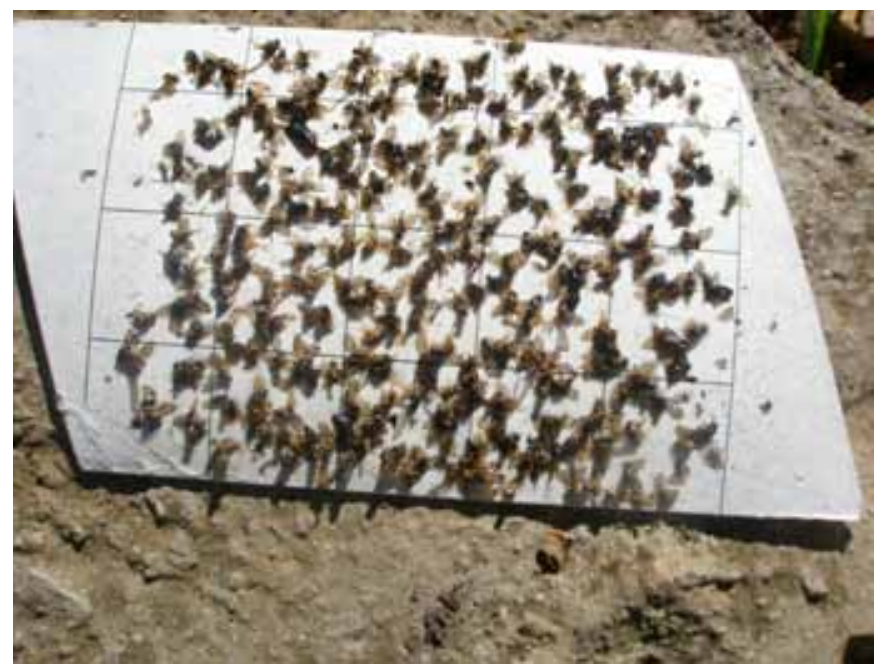

Slika/Figure 9. Ulov mediteranske voćne muhe putem lovke Izvor/Source: Autori 


\section{Granotoč (Zeuzera pyrina L.)}

Granotoč ili modro sitance predstavlja dobro poznatog i raširenog štetnika na području Hercegovine. Sredinom prošlog stoljeća Zeuzera pyrina L. evidentirana je u selu Šćit kod Prozora (Blagojević, 1958). Riječ je o polifagnom štetniku koji napada veliki broj voćnih vrsta, a njegova gusjenica se može pronaći i u tvrdim orahovim granama te stablima. Nerijetko se gusjenica ovog štetnika može naći na šipku i vinovoj lozi, a pored voćnih vrsta napada i različito šumsko drveće. Posebno je opasan kada se pojavi u mladim nasadima šipka jer tada njegovom aktivnošću može doći do propadanja nadzemnih dijelova već formiranog stabla. Osim toga, zamijećeno je kako se pored grana na mlađim stablima (starosti između dvije i pet godina) gusjenice zavlače i u deblo koje se zbog toga vrlo brzo i posuši. Od starosti stabla ovisi koliko će granotoč biti štetan. Praksa je pokazala kako je dovoljna samo jedna gusjenica granotoča da uništi mlado stablo. Međutim, štete su evidentne i na starijim voćnim stablima na kojima zbog napada ovog štetnika dolazi do sušenja grana u krošnji, slabljenja kondicijskog stanja stabala, a sve se to na koncu odražava i na smanjenje priroda.

Premda je u Hercegovini granotoč prisutan desetljećima posljednjih godina intezitet njegovog pojavljivanja sve je veći. To se podudara s trendom podizanja novih nasada šipka na način da se prilagođenom, teškom mehanizacijom kamenite i makijom obrasle površine kultiviraju i na njima se podižu nasadi. Drugim riječima osvajaju se prirodna staništa ovog štetnika koji s druge strane nije probirač u hrani (Rotim, 2015). I na koncu, ono što je dovelo do poteškoća s mnogim štetnicima karakteristično je i za granotoča. Veliki broj aktivnih tvari i pripravaka koji su se u prošlosti učinkovito koristili za suzbijanje ovog štetnika (u vrijeme izlaska gusjenica iz jaja) danas više nisu dostupni na našem tržištu.

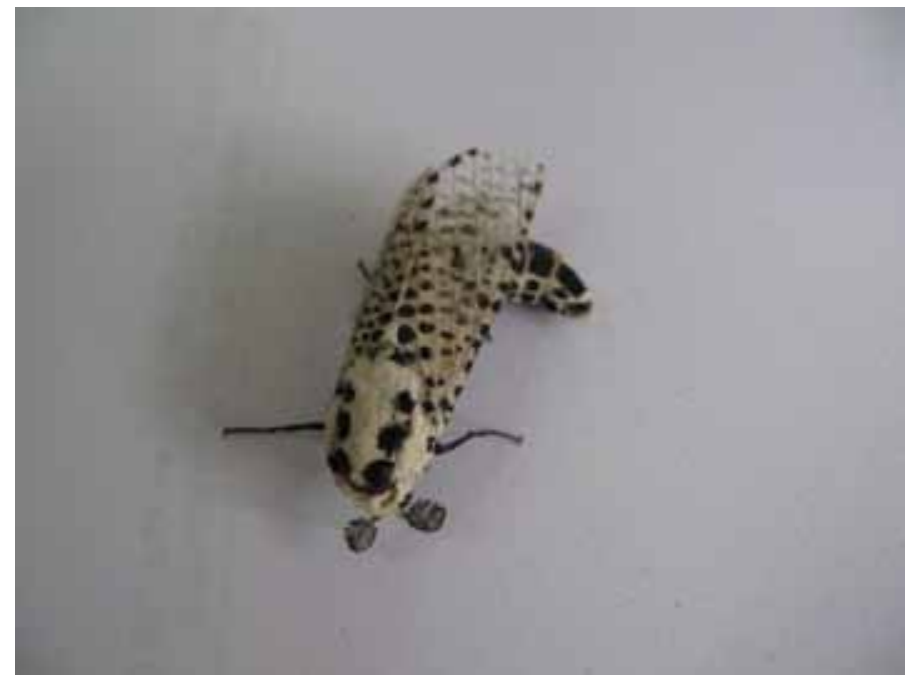

Slika/Figure 10. Imago granotoča

Izvor/Source: Autori

\section{Morfološke značajke vrste}

Ovaj štetni i dosta veliki leptir pripada familiji drvotočaca (Cossidae). Ženka je veća od mužjaka. Ima leglicu i dugačka je oko $4 \mathrm{~cm}$. Raspon krila kod ženke iznosi $5-7 \mathrm{~cm}$. Mužjak je dugačak 2-2,5 cm, a raspon krila iznosi 4,5-5 cm. Glava, prsište i krila su bijele boje dok je zadak tamnoplave boje $s$ bijelim prstenima. Na hrptenoj strani prsišta nalazi se šest modrih okrugla- 
stih točaka. Na krilima se također nalaze veće i manje okruglaste pjege tamnoplave boje koje omogućuju njegovu laku determinaciju. Na stražnjim krilima ove pjege imaju nešto svjetliju boju. Gusjenice su blijedožute boje sa sitnim tamnim točkicama po tijelu i crnosmeđom glavom, vratnim i analnim štitom. Gusjenice su heliofilne te se kreću prema svjetlu, a narastu do 6 cm. Kukuljica je poluslobodna, svijetlosmeđe boje i dugačka je oko $4 \mathrm{~cm}$.

\section{Životni ciklus}

Razdoblje leta leptira granotoča i odlaganje jaja u poneblju Hercegovine zabilježeno je od konca svibnja do početka rujna. Budući da su leptiri aktivni po noći, danju ih ne primjećujemo. Po kopulaciji ženke odlažu pojedinačno jaja na tanke grane u blizini pupoljaka ili na peteljke listova. Jedna ženka može odložiti do 1000 jaja, a jaja polaže pojedinačno na način da ih čvrsto prilijepi za podlogu. Embrionalani razvoj traje 10 do 15 dana. Iz jaja koje odlože ženke izlaze ličinke koje će ostvariti zarazu. U granama drvenastih biljaka se razvijaju dvije godine. Najprije se ličinke granotoča ubušuju u tanje periferne grančice i grane u krošnji praveći galerije ispod kore. Kroz otvor načinjen na kori izbacuju krupan izmet karakteristične boje i oblika po čemu se može ustanoviti prisutnost ovog štetnika. Do kraja svog razvića gusjenice promijene i oštete više grana. Osim grana na mlađim stablima gusjenice se mogu zavući i u deblo praveći znatno veći i uočljiviji otvor. Napadnuta stabla, stara između dvije i pet godina, uslijed tog napada obično se potpuno osuše i propadnu. Nakon drugog prezimljenja i završenog razvoja gusjenice se povlače prema izlazu gdje se kukulje da bi koncem proljeća iz kukuljice izašao novi, odrasli leptir.

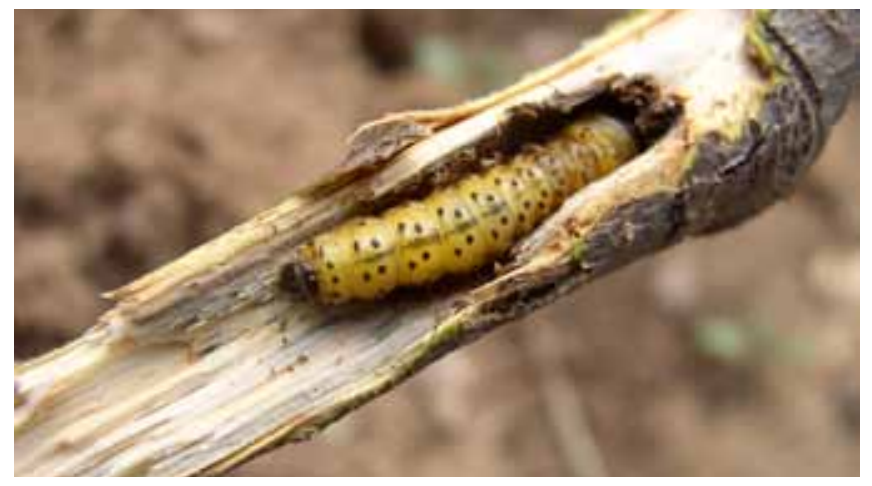

Slika/Figure 11. Ličinka granotoča u izboju šipka Izvor/Source: Autori

\section{Štete od granotoča}

Granotoč se obično u voćnim nasadima pojavljuje pojedinačno gdje pravi veoma nezgodna oštećenja. Naime, gusjenica se zavlači u srž grane gdje uslijed prehrane izaziva oštećenja u vidu sušenja i pucanja napadnutih grana. Osim toga, zbog pravljenja hodnika koji prolaze okomito kroz drvo veoma lako dolazi do preloma pojedinih grana, što je posebno izraženo u vjetrovitim područjima. Posebno je opasan štetnik u mladim nasadima šipaka gdje može izazvati sušenje i propadanje čitavih stabala. Ozbiljne štete izaziva i na starijim stablima šipka jer uzrokuje usporavanje njihovog razvoja dok pod teretom roda dolazi do preloma grana. Napadnuta stabla su uslijed oslabljenog kondicijskog stanja podložna napadu drugih štetnika kao što su potkornjaci. Uočeno je kako su veća oštećenja od granotoča u nasadima gustog sklopa iz razloga što napadnuta stabla slabo listaju, smanjeno cvjetaju i na kraju se suše iznad donjeg 
mjesta ishrane gusjenice što je čini znatno štetnijom u odnosu na slobodni uzgoj. Nadalje, primjećeno je da češće stradaju stabla koja nemaju dovoljnu opskrbu vodom. Štetnost granotoča tim je veća ukoliko je poznato kako napada zdrava stabla i to vrlo uporno ne napuštajući ga ako ga već jednom napadnu. Posebice je to izraženo u prigradskim naseljima i malim gradskim vrtovima jer je riječ o fotofilnim leptirima koje privlače žarulje ulične rasvjete zbog čega najveći broj jaja i odlažu na okolna stabla takvih sredina.

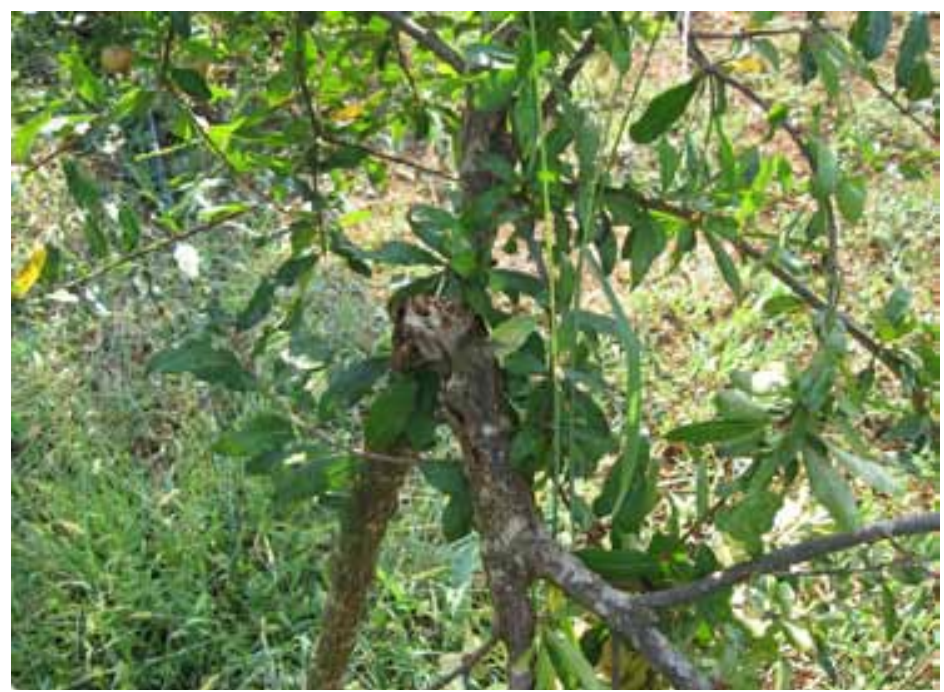

Slika/Figure 12. Štete od granotoča

Izvor/Source: Autori

\section{Suzbijanje}

Suzbijanje granotoča i njemu sličnih štetnika koji većinu svog razvoja provode u unutrašnjosti grana je prilično komplicirano. Uostalom, zbog skrivenog života ličinki u praksi se njegovo suzbijanja kemijskim putem rijetko provodi. Osnovna mjera u ovom pogledu jest pravodobno utvrđivanje njegove prisutnosti u voćnjaku. U praksi se to provodi primjenom lovki sa feromonima koje se koriste za monitoring i ulov granotoča. Koristi se 10-15 lovki po hektaru na način da se lovke postavljaju visoko, u predjelu iznad krošnje odnosno tamo gdje je zona leta leptira. Tretiranje insekticidima ima učinak samo u stadiju mladih ličinki, ali na našem tržištu nema pripravaka za tu namjenu registriranih za primjenu na šipku. Kurativno se u otvore koje je načinio ovaj štetnik mogu uštrcavati u nekoliko puta većoj koncentraciji insekticidi jače volatilnosti nakon čega se otvor zatvori voćarskim voskom. Međutim, prije primjene insekticida potrebno je u načinjeni otvor ugurati žicu sa savijenim vrhom i pokušati mehanički izvući gusjenicu, a sve u slučaju da se još uvijek nalazi u blizini načinjenog otvora. Bitno je napomenuti kako voćari u borbi s ovim štetnikom koriste i neke druge alternativne metode na način da u otvor naguravaju pamuk natopljen benzinom, eterom ili kloroformom. Nakon toga otvor zatvore voćarskim voskom. To čine iz razloga što spomenuta sredstva isparavaju, a njihove otrovne pare ponekad budu učinkovite i mogu ubiti gusjenicu. Kada poduzete mjere ne daju rezultata poželjno je jače napadnuta stabla ili grane ispilati i čim prije zapaliti. Pri odstranjivanju grana treba voditi računa da se odreže i dio gdje se nalazi gusjenica. Pogrešno je takva stabla ili grane isjeći i ostaviti za ogrjev jer gusjenice ih mogu napustiti i ponovno se ubušiti u nova, okolna stabla. 


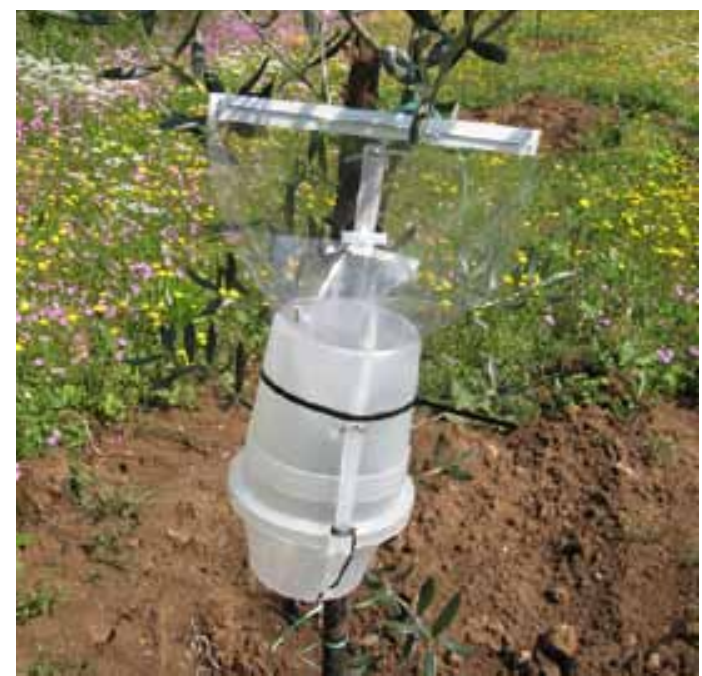

Slika/Figure 13. Feromonska lovka za granotoča

Izvor/Source: Autori

U nasadima i pojedinačnim stablima šipka na području Hercegovine mogu se uočiti i drugi štetni organizmi koji ne pričinjavaju značajnije štete.

Egipatski skakavac (Anacridium aegyptium L.) se često može zamijetiti na stablima šipka koja se uzgajaju na pojedinim lokalitetima u Hercegovini (općina Neum). Općenito gledano skakavci ne izazivaju značajnija oštećenja na šipku premda u slučaju masovnije pojave mogu pričiniti izvjesne štete nagrizajući zelene dijelove stabala. Međutim, egipatski skakavac je naša najveća vrsta pravih skakavaca koja se uglavnom pojavljuje pojedinačno zbog čega su i štete neznatne odnosno sporadične. Tijelo mu je sivosmeđe boje čija duljina iznosi $5-7 \mathrm{~cm}$. Na području općine Neum redovito je prisutan u prirodnim sastojbinama makije i niskih grmova odakle dolijeće na stabla šipaka, a na istom području se na stablima šipka može uočiti i zrikavac vrste Ephippiger ephippiger Fieb.

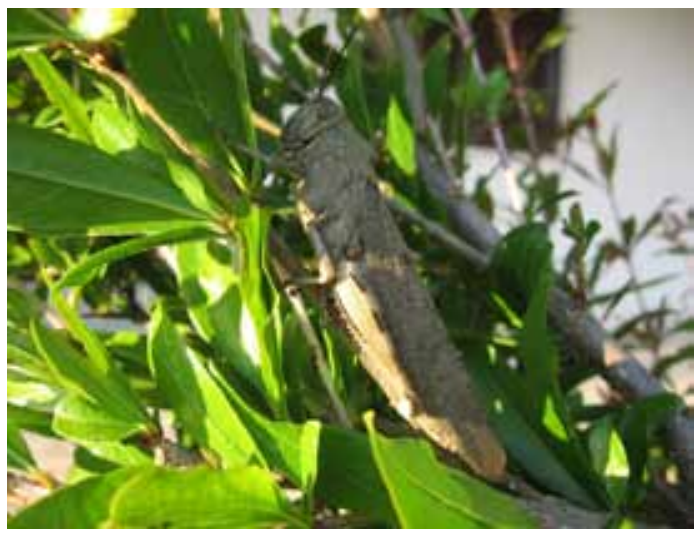

Slika/Figure 14. Egipatski skakavac na stablu šipka Izvor/Source: Autori 
Puževi u godinama s većom količinom oborina i u slučaju prenamnoženja mogu načiniti manja oštećenja na stablima šipaka i sadnicama u rasadnicima. Međutim, te štete nisu nikada značajnijeg karaktera. Na hercegovačkom priobalju (općina Neum) na stablima šipka često se može zamijetiti vrsta puža Eobania vermiculata koja se zbog svoje veličine lako uočava. Dovoljna mjera je sakupljanje nakon kiše kada puževi iziđu iz svojih skrovišta i rašire se po nasadu.

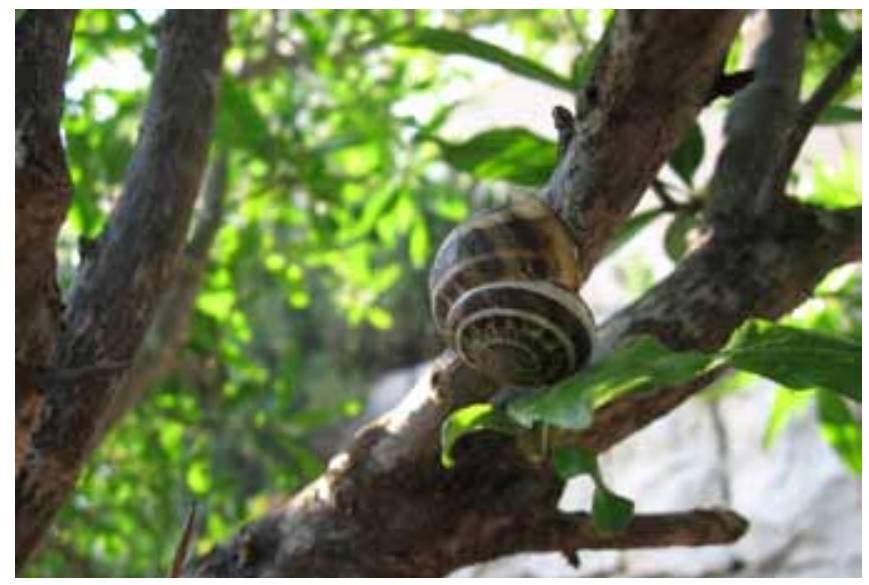

Slika/Figure 15. Puževi su često nazočni na stablima šipka u priobalju Slika/Source: Autori

Uholaža (Forficula auricularia L.) je poznati kukac koji na kraju tijela ima izraštaje nalik na kliješta (cerci). Često se može zamijetiti na različitom voću, ali kao štetnik rijetko dolazi do izražaja. Tijekom dana obitava u mračnim i vlažnim skrovitim mjestima. Uholaža je aktivna tijekom noći kada se hrani lisnim ušima, grinjama i jajima leptira čime smanjuje bronost štetnih insekata pa se njena prisutnost u voćnjacima smatra korisnom. Na šipku ne čini štete osim što kod konzumenata plodova svojom nazočnošću izaziva nelagodu skrivajući se na vrhu ploda u vijencu od preostalih čašičnih listića koje onečišćuje svojim izmetom.

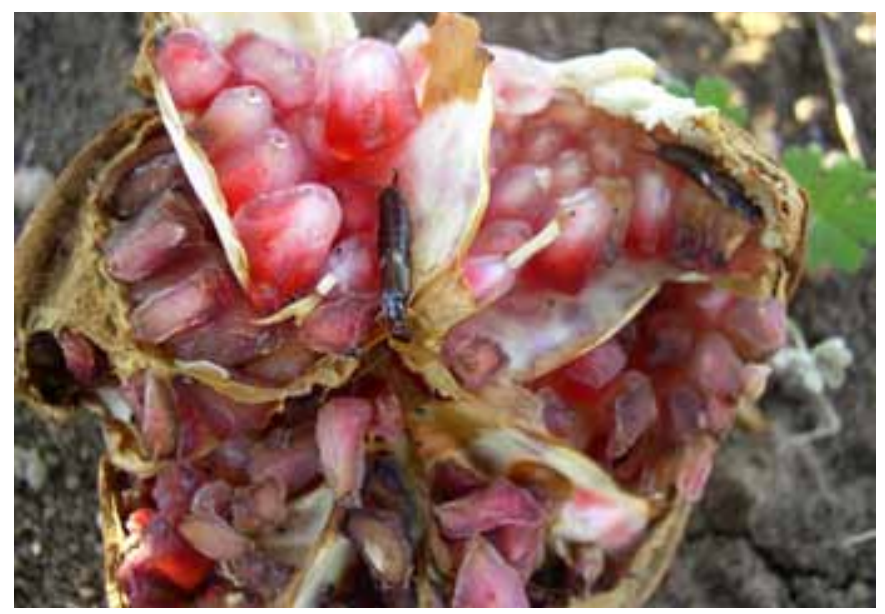

Slika/Slika 16. Uholaža u plodu sipka Izvor/Source: Autori 


\title{
Literatura
}

Abd-Rabou, S. (1998) The efficacy of indigenous parasitoids in the biological control of Siphoninus phillyreae (Homoptera: Aleyrodidae) on pomegranate in Egypt. Pan-Pacific Entomologist, 74, 169-173.

Bellows, T.S., Paine T.D., Arakawa KY, Meisenbacher C., Laddy P., Kabashima J. (1990) Biological control sought for ash whitefly. California Agriculture, 44(1), 4-6.

Blagojević, M. (1958) Biljni paraziti i štetočine u Hercegovini u toku 1954-1956 godine, poseban otisak iz časopisa "Zaštita bilja", 45, Beograd

Bulić, P., Bohm, D., Ostojić, I., Bjeliš, M., Gakić, S., Marušić, I. (2011) Prva iskustva primjena SIT (Sterile Insect Technique) metode u suzbijanju mediteranske voćne muhe (Ceratitis capitata Wied.) na području Hercegovine. U: Zbornik sažetaka 8. Simpozij o zaštiti bilja u Bosni i Hercegovini, Teslić, 08-10. 11. 2011. godine, str. 69.

Bulić, P., Bohm, D., Gakić, S., Marušić, I., Popović, L., Ostojić, I., Bjeliš, M. (2012) Mediteranska voćna muha (Ceratitis capitata Wied.) - istraživanje nekih elemenata biološkog ciklusa. U: : Zbornik sažetaka 9. Simpozij o zaštiti bilja u Bosni i Hercegovini 9, Teslić, 06-08. 11. 2012. godine, str. 69.

Malumphy, C. (2010) Ash whiteflies, Siphoninus phillyreae (Haliday) (Hemiptera: Aleyrodidae), Damaging olive plants for the first time in Britain. Entomologists Monthly Magazine, 146, 207-208.

Martin, J.H., Mifsud, D., Rapisarda, C. (2000) The whiteflies (Hemiptera: Aleyrodidae) of Europe and Mediterranean Basin. Bull. Entomol. Res, 90, 407-448.

Ostojić, I., Zovko, M., Petrović, D., Rotim, N., Bulić, P., Dogan, V. (2014) Jasenov štitasti moljac (Siphoninus phillyrea, Haliday) - sve značajniji štetnik šipka na području Hercegovine. U: Zbornik sažetaka 11. Simpozij o zaštiti bilja u Bosni i Hercegovini, Teslić, 04-06. 11. 2014. godine, str. 40-41.

Ostojić, I., Zovko, M., Petrović, D., Bulić, P. (2014) Results of five year monitoring of mediterranen fruit fly (Ceratitis capitata Wied.) in Herzegowina. Works of the Faculty of Agricultural and Food Sciences, University of Sarajevo, LIX, 64/1, 7-19.

Peljto, Amela, Trkulja, V., Ostojić, l., Rotim, N., Đikić, Mirha (2007) Suzbijanje bolesti, štetnika i korova koštičavih voćaka. Banja Luka: Društvo za zaštitu bilja u BiH,

Pickett, C.H., Ball, J.C., Casanave, K.C., Klonsky, K.M., Jetter, K.M., Bezark, L.G., Schoenig, S.E. (1996) Establishment of the ash whitefly parasitoid Encarsia inaron (Walker) and its economic benefit to ornamental street trees in California. Biological Control 6, 260-272.

Projekt inventarizacije nasada šipka u Hercegovini (2012), Federalni agromediteranski zavod Mostar.

Rotim, N., Ostojić, I. (2014) Jasenov štitasti moljac (Siphoninus phillyrea) opasan štetnik šipka u Hercegovini. Glasnik zaštite bilja, 5, 54-57.

Rotim, N. (2015) Granotoč (Zeuzera pyrina L.) opasan štetnik mladih nasada u Hercegovini. Glasnik zaštite bilja, 4, 91-93.

Vego, Dijana, Ostojić, I., Rotim, N. (2009) Šipak-priručnik za voćare. Mostar: Udruga „IPERRA“

\section{Professional paper}

\section{Significant pests of the pomegranate tree on the territory of Herzegovina}

\begin{abstract}
Pomegranate tree (Punica granatum) is cultivated in Herzegovina on the surface of 54,41 hectares. Within 58 intensive pomegranate plantations 43.248 trees of this fruit tree were recorded. With rising of intensive plantations of pomegranate, numerous pests which endanger production and cause economically significant damages appeared. Significant pests in pomegranate plantations in the territory of Herzegovina are: Myzus persicae, Siphoninus phillyrea, Ceratitis capitata and Zeuzera pyrina. Biological and ecological characteristics of the pests and the possibility of protection of the pomegranate tree will be shown in the work.
\end{abstract}

Key words: intensive pomegranate plantations, pests, economically significant damages 